\author{
Russell F Mankes ${ }^{1-3},{ }^{*}$ and Charles D \\ Silver $^{4}$ \\ ${ }^{1}$ Associate Professor (Retired), Center for \\ Neuropharmacology \& Neuroscience; Albany \\ Medical College, 47 New Scotland Avenue Albany \\ NY 12208, USA. \\ ${ }^{2}$ Associate Professor \& Responsible Official (Retired), \\ Center for Immunology \& Microbial Disease, Albany \\ Medical College, 47 New Scotland Avenue Albany \\ NY 12208, USA \\ ${ }^{3}$ Chemical Hygiene Officer (Retired), Department \\ of Environmental Health \& Safety (MC-96) Albany \\ Medical Center 43 New Scotland Avenue Albany NY \\ 12208, USA. \\ ${ }^{4} \mathrm{New}$ York City Watershed Inspector General \\ Scientist, New York State Office of the Attorney \\ General, Environmental Protection Bureau, The \\ Capitol, Albany, NY 12224-0341. USA. \\ "The Office of the New York State Attorney General \\ does not endorse the views expressed in this article. \\ All opinions represent those of Charles D. Silver and \\ not the Attorney General's Office."
}

Dates: Received: 09 December, 2015; Accepted: 29 December, 2015; Published: 07 January, 2016

*Corresponding author: Russell F. Mankes, Ph.D., 141 Mohawk Drive, Schenectady, NY 12303; E-mail: Russell.Mankes@Gmail.com

ISSN: 2641-2969

www.peertechz.com

Keywords: Antibiotic; Stewardship; Resistance; Waste; Eco toxicity; Wastewater

\section{Research Article \\ Hospital Antibiotic Wasting and Evaluation of Potential Ecologic Effects}

\begin{abstract}
Drugs in wastewater arise from direct disposal by healthcare facilities among many other sources. We report the wasting of antibiotics (Ab) dispensed at 2 hospitals in Albany, NY during a 2 year period. We consider drug metabolism, excretion, disposal and toxicity to aquatic organisms in strategies for reducing antibiotic waste and impacts on bacterial resistance.

Drug records $(12,345)$ from August, 2008 through April, 2009 included: numbers of drugs dispensed, returned and wasted. Overall, $77 \mathrm{~kg}$ of Ab were dispensed but only $1.3 \mathrm{~kg}$ were wasted. $\mathrm{Six}$ Ab (bacitracin, cefazolin, ceftriaxone, clindamycin, levofloxacin and vancomycin) accounted for $85 \%(66 \mathrm{~kg})$ of drug dispensed; vancomycin $(22 \mathrm{~kg})$ was the most dispensed. Drug wasting as a percent of drug dispensed averaged $1.7 \%$ but varied widely. Almost one-half (45\%) of the polymyxin B dispensed as a topical ointment was wasted or discarded. Only about $1.6 \%$ of vancomycin dispensed was wasted or discarded.

None of the top 4 wasted and only 3 of the top 6 dispensed Ab had Persistence, Bioaccumulation and Toxicity (PBT) Index values or environmental risk ratio (PEC/PNEC) data available. Vancomycin was minimally toxic to invertebrates, fish or green algae. Bacitracin was the most toxic to invertebrates or fish. Cefazolin was essentially non-toxic to green algae. All of the wasted, discarded or dispensed $\mathrm{Ab}$ were excreted as parent compound in the urine and or feces of human patients at levels of 10 $100 \%$ of the administered dose.

In healthcare facilities, $A b$ are disposed by wasting into water or other receptacles. We recommend returning excess drugs to the hospital pharmacy for incineration as the recommended method of disposal. Ab use and dispensing should be monitored according to recognized guidelines of antimicrobial stewardship. Knowledge of the adverse impacts from the release of highly toxic drugs into the environment must influence Ab selection and disposal.
\end{abstract}

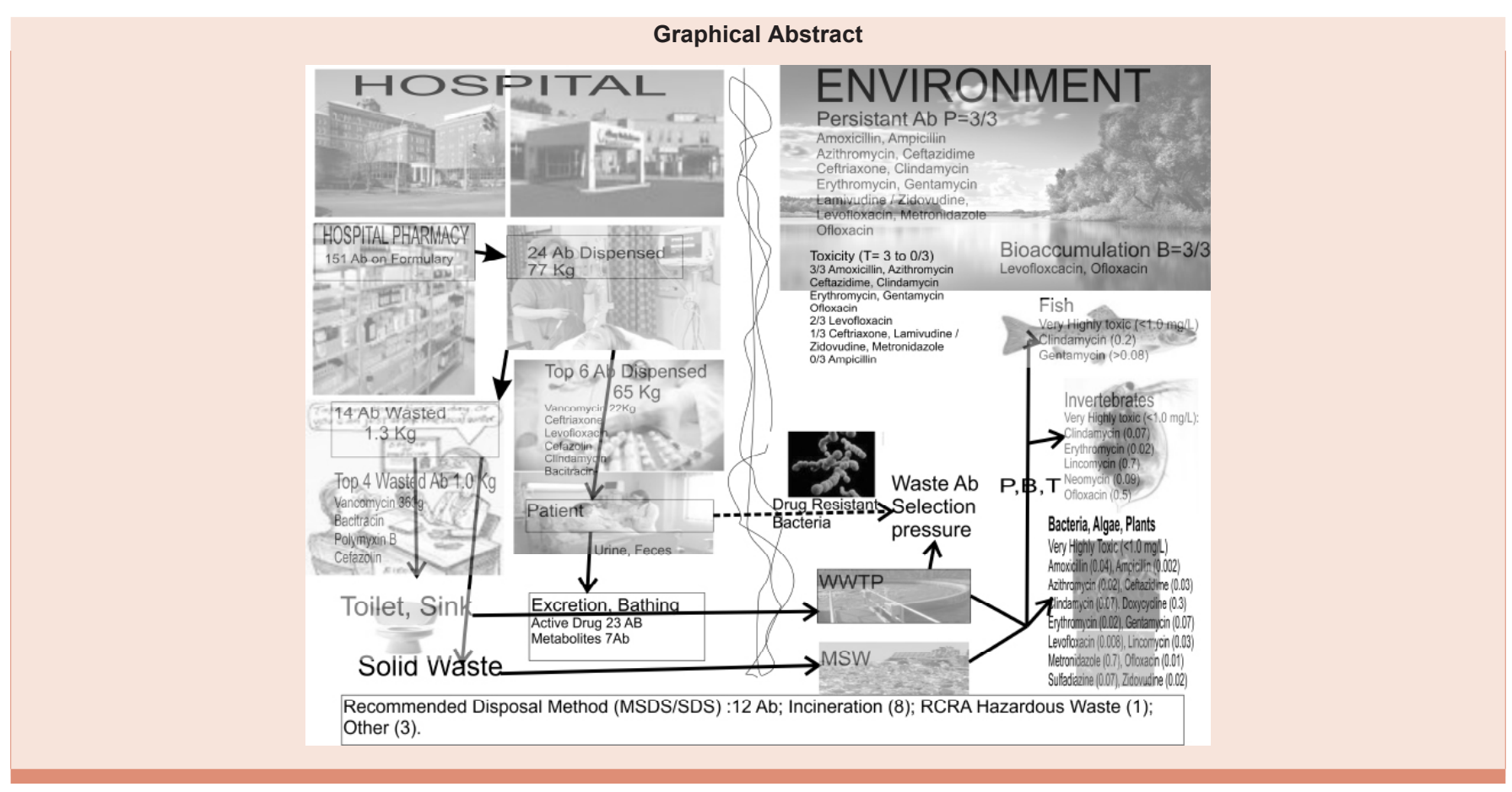




\section{Abbreviations}

AMCH: Academic Medical Center Hospital; ASTER: Assessment Tools for the Evaluation of Risk. United States Environmental Protection Agency http://www;epa;gov/med/prods_pubs/aster;htm; Last accessed $8 / 20 / 15$; B: Bioaccumulation is the general term describing a process by which chemicals are taken up by an organism either directly from exposure to a contaminated medium or by consumption of food containing the chemical. US Environmental Protection Agency. Solid waste and emergency response glossaryBioaccumulation http://www;epa;gov/oswer/riskassessment/ glossary;htm\#b; Last accessed 8/20/15; BOD: Biological Oxygen Demand is the amount of dissolved oxygen needed by aerobic biological organisms in a body of water to break down organic material present in a given water sample at a certain temperature over a specific time period; COD: Chemical Oxygen Demand is the standard method for indirect measurement of the amount of pollution (that cannot be oxidized biologically) in a sample of water; $\mathrm{EC}_{50}$ : Effective Concentration producing an adverse effect in $50 \%$ of a test species; $\mathrm{EbC}_{50}$ or $\mathrm{ErC}_{50}: \mathrm{EC}_{50}$ in terms of reduction of growth rate; $\mathrm{EyC}_{50}: \mathrm{EC}_{50}$ in terms of change in biomass yield; Ecosar: Ecologic Structure Activity Relationships is a computerized predictive system that estimates aquatic toxicity. The program estimates a chemical's acute (short-term) toxicity and chronic (long-term or delayed) toxicity to aquatic organisms such as fish, invertebrates, and plants by using computerized Structure Activity Relationships (SARs). http:// www;epa;gov/oppt/newchems/tools/21ecosar.htm. Last accessed 8/20/15; EPA: United States Environmental Protection Agency; FDA: United States Food and Drug Administration; $\mathrm{IC}_{50}$ : Half maximal inhibitory concentration $\left(\mathrm{IC}_{50}\right)$ is a measure of the effectiveness of a substance in inhibiting a specific biological or biochemical function; $\mathrm{LC}_{50}$ : Lethal Concentration producing $50 \%$ mortality in test species; MIC: Minimum Inhibitory Concentration (MIC) is the lowest concentration of an antimicrobial that will inhibit the visible growth of a microorganism after overnight incubation; MSDS: Material Safety Data Sheet; Since 2009, known as SDS or Safety Data Sheet; Neutral Organics QSAR: Subset of chemicals within Ecosar Suite; OECD: Organization for Economic Cooperation and Development; P: Persistence is the length of time a substance resides in the environment; PBT: Persistence, Bioaccumulation, Toxicity index (http://www;janusinfo.se); PEC: Predicted Environmental Concentration; PNEC: Predicted No Effect Concentration, highest concentration of a substance that does not have a harmful effect in the environment; PNN: Probabilistic Neural Network modeling; QSAR: Quantitative Structure Activity Relationship; REACH: Registration, Evaluation and Authorization of Chemicals legislation of the European Union; SAR: Structure Activity Relationship; SCC: Surgical Care Center; STP: Sewage Treatment Plant; T or iT: Toxicity or Inherent Toxicity is the hazard a substance presents to the environment or human health; TSDF: Treatment, Storage and/or Disposal Facility for processing of chemical wastes;

\section{Background}

Healthcare drug wasting is a significant environmental, financial and public health concern [1]. Trace levels of antibiotics $(\mathrm{Ab})$, endocrine disruptors, psychotropics, anti-inflammatory and mood altering drugs have been detected in wastewaters, surface waters, and drinking water supplies for major world cities [2-8]. Drug residues have been found in tissues of aquatic organisms [9]. Pharmaceuticals are introduced into the aquatic environment from a variety of sources, such as: hospitals [10,11]; wastewater [12]; drug manufacturers $[13,14]$, livestock, animal feeding operations and veterinary facilities [15-17]. Excessive dispensing and improper disposal of pharmaceuticals results in inflated healthcare costs and contamination of the environment $[10,11]$.

Antibiotic/antimicrobial $(\mathrm{Ab})$ drugs are but one important class of pharmaceutical and personal care products found contaminating the environment from a wide variety of sources. These drugs are prescribed to treat disease in animals, including humans, and to enhance growth of livestock and aquaculture. As a group, they are some of the most prescribed pharmaceuticals [18]. Adverse effects on the environment may arise from overuse and improper disposal of antibiotic/antimicrobial drugs leading to the emergence and dissemination of $\mathrm{Ab}$ resistant organisms [19]. Ab can be toxic to natural bacterial communities, impede organic matter degradation and disrupt bacterial nitrification/denitrification processes [20-22]. $\mathrm{Ab}$ are thus considered a priority risk group due to their high toxicity to bacteria and algae at low concentrations and their potential to initiate resistance amongst natural bacterial populations [23].

Many $\mathrm{Ab}$ are not completely metabolized or retained in the body and much of the active drug is excreted unchanged into the waste system $[24,25]$. Studies conducted on water quality in various countries have detected a number of antibiotics in the low $\mu \mathrm{g} / \mathrm{L}$ or parts per billion range. Ab have been reported in surface water, groundwater, sediment, and soil [18,26-32].

In a prior publication [33], the patterns of wasting and potential environmental effects of propofol and other surgical drugs (e.g. atracurium, atropine, bupivacaine, ephedrine, epinephrine, lidocaine, proparacaine and succinylcholine) were reported from a surgical care center in Albany, NY. Of interest was how a small change in availability (e.g., removal of 50 and $100 \mathrm{~mL}$ propofol) reduced propofol wastage from 29.2 to $2.8 \mathrm{~mL}$ /day/bin. In a second communication [34], wasting of 15 controlled substance from two hospitals in Albany, New York were evaluated over a two year period, finding 3 (acetaminophen-codeine, fentanyl and midazolam) contributed nearly $90 \%$ of the total waste. The present study reports on the dispensing and wasting of selected antibiotics (Ab) given to patients at two health care facilities in Albany, NY over a nearly two year period. The study considered drug metabolism, excretion, disposal and toxicity to aquatic organisms (ecotoxicity). Strategies for antibiotic waste minimization and impacts on bacterial resistance from healthcare facilities are discussed.

\section{Materials and Methods}

As part of a pharmaceutical waste reduction pilot program, a total of 12,345 drug records for dispensing and waste collection were reviewed over a two year period (2008 and 2009) from two hospitals in Albany, NY. There were 4,889 automated drug dispensing machine $\left(\mathrm{PYXIS}^{\circledR}\right)$ records which were collected and tabulated for a one week period in April 2009 at the Albany Medical Center Hospital (AMCH; 
630-bed, acute care) and 7,257 PYXIS $^{\circledR}$ records from the South Clinical Campus (SCC; 20 bed surgical care center) from August 2008 through February 2009. Additionally, the contents of 199 pharmaceutical waste collection containers placed at SCC were sorted by hand and their contents tabulated.

Data were recorded by location, medication form, weight and number of units dispensed, returned, "bedside wasted" or discarded (e.g., a $1 \mathrm{~g}$ dose of cefazolin was recorded as $1 \mathrm{~g}$ regardless of the total weight of the drug formulation.). No human subject or patient identifier information was accessed; all data were recorded as summary aggregates. The funding agency (EPA) did not participate in the design, conduct, or analysis of the study. All numeric data were entered and archived on a Windows ${ }^{\circledR}$ based personal computer and analyzed by standard software packages (Microsoft Access ${ }^{\circledR}, \operatorname{Excel}^{\circledR}$ ).

N.b., Bedside wasted at health care facilities refers to the discharge of excess drug withdrawn for patient administration but only partially given to a patient. The leftover medication was then discarded by a healthcare professional who documented the wasting in the medication record.

Persistence, bioaccumulation, toxicity (PBT), environmental risk ratio (http://www.janusinfo.se), and ecotoxicity (http://www. msdsonline.com) were summarized for each drug wasted or discarded and displayed in Table 1 and Supplemental Table 1.

Table 1 (and Supplemental Table 1) provides laboratory-derived acute toxicity information ( $<96$ hours). Acute inhibitory and lethal concentration data were considered to be the same for our review (e.g., $\mathrm{EC}_{50}=\mathrm{IC}_{50}=\mathrm{LC}_{50}$ ). In all cases, the $\mathrm{EC}_{50}, \mathrm{IC}_{50}$, and $\mathrm{LC}_{50}$ value was selected from the data as it represents the most reproducible point on the dose-response curve.

In addition to the laboratory derived toxicity information presented in the MSDS/SDS and outside literature, mathematically modeled values are provided in Table 1 (and Supplemental Table 1): Aster (http://www.epa.gov/med/prods_pubs/aster.htm), ECOSAR (Ecological Structure Activity Relationships - http://www.epa.gov/ oppt/newchems/tools/21ecosar.htm ), Neutral Organics QSAR (Quantitative Structure Activity Relationship), Oasis Forecast M, PNN, and Topkat [35-37].

Pharmacokinetic data (metabolism, conjugation and excretion) are summarized in Table 2 (and Supplemental Table 2) from official government drug monographs and labels (Drugs@FDA; http:// www.accessdata.fda.gov/scripts/cder/drugsatfda/index.cfm) and the Hazardous Substances Data Bank, United States National Library of Medicine TOXNET Toxicology Data Network (http://toxnet.nlm. nih.gov/cgi-bin/sis/htmlgen?HSDB).

For those drugs for which no data (designated as ND) were found for PBT, environmental risk ratio, ecotoxicity or pharmacokinetics, a computerized search of the available primary literature was done (http://www.ncbi.nlm.nih.gov/pubmed) and referenced in footnotes to Tables 1, 2 (and Supplemental Tables 1,2).

\section{Results}

\section{Antibiotics wasted or dispensed}

As shown in Figure 1, a total of $1316 \mathrm{~g}$ of 14 antibiotic/antimicrobial
(Ab) drugs were wasted and discarded. Four Ab (vancomycin, bacitracin, polymyxin B and cefazolin) accounted for $1093 \mathrm{~g}$ (83\%) of the total discarded/wasted drugs. Vancomycin was the most wasted with $363 \mathrm{~g}$, followed by bacitracin (335 g), polymyxin B (222 g) and cefazolin (173 g; Figure 1). Vancomycin was also the most dispensed $(22,059 \mathrm{~g})$ of the $24 \mathrm{Ab}$ given to patients at $\mathrm{AMCH}$ and SCC (Figure 2). Five other $A b$ (ceftriaxone, levofloxacin, cefazolin, clindamycin, and bacitracin) plus vancomycin accounted for over $80 \%$ (65,697 $\mathrm{g}$ of $77,108 \mathrm{~g}$ ) of all of the antimicrobial drugs given to patients (Figure 2).

Drug wasting as a percent of drug dispensed averaged 1.7\% but varied widely. Almost one-half (45\%) of the polymyxin B dispensed as a topical ointment was wasted or discarded. Only about $1.6 \%$ of vancomycin dispensed was wasted or discarded (see supplemental Figure 3).

\section{PBT and Environmental Risk Ratio (PEC/PNEC) of Healthcare Ab}

As depicted in Table 1 none of the top 4 wasted and only 3 (ceftriaxone, clindamycin and levofloxacin) of the top 6 dispensed $\mathrm{Ab}$ have PBT index values or environmental risk ratio (PEC/PNEC) data available. PBT index values for the $3 \mathrm{Ab}$ averaged 6.0 and ranged from 4 of 9 (ceftriaxone) to 8 of 9 (levofloxacin). All three are very persistent ( $\mathrm{P}$ value 3 of 3 ). Only levofloxacin is very bioaccumulative (B value 3 of 3). Ceftriaxone and clindamycin are not bioaccumulative (B value 0 of 3 ) but are "very highly toxic" (T value 3 of 3 ). Levofloxacin is "highly toxic" (T value 2 of 3 ). Environmental risk ratio (PEC/PNEC) for ceftriaxone is considered insignificant, ceftazidime is low and clindamycin is considered "Cannot Be Excluded" (Table 1).

\section{Ecotoxicity Potential of Healthcare Ab Dispensed or Wasted to the Aquatic Environment}

Vancomycin, the most wasted and dispensed $\mathrm{Ab}$, was minimally toxic $\left(48,96 \mathrm{~h} \mathrm{LC}_{50}\right.$ from $264 \mathrm{mg} / \mathrm{L}$ to $\left.>1000 \mathrm{mg} / \mathrm{L}\right)$ to invertebrates, fish or green algae based solely on computer model data for ecotoxicity (Table 1). Bacitracin was the most toxic of the top 4 wasted Ab to invertebrates (Daphnia $48 \mathrm{~h} \mathrm{EC}_{50} 30 \mathrm{mg} / \mathrm{L}$; Artemia $48 \mathrm{~h} \mathrm{EC}_{50} 22$ $\mathrm{mg} / \mathrm{L}$ ) or fish (96 h LC $5074 \mathrm{mg} / \mathrm{L}$ ) based on MSDS and published data. Cefazolin was essentially non-toxic $\left(48 \& 96 \mathrm{~h} \mathrm{LC}_{50}>1000 \mathrm{mg} / \mathrm{L}\right)$ to invertebrates, fish or green algae based on literature values and computer model data for ecotoxicity.

Of the top six dispensed Ab (vancomycin, ceftriaxone, levofloxacin, cefazolin, clindamycin, and bacitracin); clindamycin is very highly toxic to invertebrates (Daphnia $48 \mathrm{~h} \mathrm{EC}_{50}<0.1 \mathrm{mg} / \mathrm{L}$ ) and to fish (Oryzias, Poecilia $96 \mathrm{~h} \mathrm{EC}_{50}<1.0 \& 2.0 \mathrm{mg} / \mathrm{L}$ ). Clindamycin and levofloxacin are very highly toxic $\left(\mathrm{EC}_{50}, \mathrm{IC}_{50}\right.$ or $\left.\mathrm{LC}_{50}<1.0 \mathrm{mg} / \mathrm{L}\right)$ to algae and bacteria (Table 1). Levofloxacin has a $7 \mathrm{~d} \mathrm{EC}_{50}$ to Microcystis $<0.01 \mathrm{mg} / \mathrm{L}$.

\section{Recommended disposal of $\mathrm{Ab}$.}

Incineration was recommended by the MSDS/SDS for ceftriaxone and clindamycin. Biological waste treatment was recommended for cefazolin. Vancomycin, bacitracin, polymyxin B, and levofloxacin had no method of disposal recommended by the MSDS/SDS. 
Table 1: Summary of the Ecotoxic Potential of Antibiotic/Antimicrobial Drugs Dispensed and/or Wasted at an Academic Medical Center Hospital and at a Surgical Care Center in Albany, NY.

\begin{tabular}{|c|c|c|c|c|c|c|}
\hline $\begin{array}{l}\text { Antibiotic }^{a} \\
\text { Drug Generic } \\
\text { Name } \\
\text { CAS Number }\end{array}$ & & & & Ecotoxicity & & \\
\hline \multicolumn{7}{|c|}{ Antibiotic / Antimicrobial Drugs Most Frequently (top 80\%) "Wasted" and Discarded } \\
\hline $\begin{array}{l}\text { Vancomycin } \\
1404-90-6 \\
(\text { VANCOCIN }()\end{array}$ & $N^{f}$ & ND & $\begin{array}{l}\text { MSDS/SDS: ND } \\
\text { Literature: ND } \\
\\
\text { Predicted: Daphniag } \text { LC }_{50}{ }^{\mathrm{h}} \\
264 \mathrm{mg} / \mathrm{L} \mathrm{48h;} \mathrm{mysidi} \mathrm{LC}_{50} \\
>1000 \mathrm{mg} / \mathrm{L} 96 \mathrm{~h} \text { (Ecosar } \\
\text { v1.11) } \\
\end{array}$ & $\begin{array}{l}\text { MSDS/SDS: ND } \\
\text { Literature: ND } \\
\text { Predictedi: Fish } \mathrm{LC}_{50}>1000 \\
\mathrm{mg} / \mathrm{L} \text { 96h; SW }>1000 \mathrm{mg} / \mathrm{L} \\
\text { (Ecosar v1.11) }\end{array}$ & $\begin{array}{l}\text { MSDS/SDS: ND } \\
\text { Biodegradation enhanced during ozonation } \\
{[89,90] .} \\
\text { Predicted: Green algae } \mathrm{EC}_{50}{ }^{\mathrm{k}}>1000 \mathrm{mg} / \mathrm{L} \\
\text { 96h (Ecosar v1.11); PNEC } 0.32 \mathrm{mg} / \mathrm{L}\end{array}$ & MSDS/SDS: ND \\
\hline $\begin{array}{l}\text { Bacitracin } \\
1405-87-4 \\
(B A C i i M \circledR)\end{array}$ & $\mathrm{ND}^{\mathrm{g}}$ & ND & $\begin{array}{l}\text { MSDS/SDS: Daphnia } \mathrm{EC}_{50} \\
30 \mathrm{mg} / \mathrm{L} 48 \mathrm{~h} . \\
\\
\text { Literature: Daphnia } \mathrm{EC}_{50} \\
126 \mathrm{mg} / \mathrm{L} 24 \mathrm{~h} ; 30 \mathrm{mg} / \mathrm{L} 48 \mathrm{~h} \\
{[76] ; \mathrm{LC}_{50} 34 \mathrm{mg} / \mathrm{L} \mathrm{48h} \mathrm{[77];}} \\
\text { Artemia }^{n} \mathrm{EC}_{50} 34 \mathrm{mg} / \mathrm{L} 24 \mathrm{~h} \\
\& 22 \mathrm{mg} / \mathrm{L} 48 \mathrm{~h}[78] . \\
\text { Predicted: ND }\end{array}$ & $\begin{array}{l}\text { MSDS/SDS: ND } \\
\text { Literature: Salmom } \text { LC }_{50} 74 \mathrm{mg} / \mathrm{L} \\
\text { 96h [77]. } \\
\text { Predicted: Fish >1000 mg/L } \\
\text { (Neutral Organics QSAR) } \\
\end{array}$ & MSDS/SDS, Literature, Predicted: ND & MSDS/SDS: ND \\
\hline $\begin{array}{l}\text { Polymyxin B } \\
1405-20-5\end{array}$ & ND & ND & $\begin{array}{l}\text { MSDS/SDS, Literature, } \\
\text { Predicted: ND }\end{array}$ & $\begin{array}{l}\text { MSDS/SDS, Literature, } \\
\text { Predicted: ND }\end{array}$ & MSDS/SDS, Literature, Predicted: ND & MSDS/SDS: ND \\
\hline $\begin{array}{l}\text { Cefazolin } \\
25953-19-9 \\
\text { (ANCEF®) }\end{array}$ & ND & ND & $\begin{array}{l}\text { MSDS/SDS, Literature: ND } \\
\text { Predicted: Daphnia LC } \\
>1000 \mathrm{mg} / \mathrm{L} ; \text { mysid } \text { LC }_{50} \\
>1000 \mathrm{mg} / \mathrm{L} \text { 96h (Ecosar } \\
\text { v1.11g) }\end{array}$ & $\begin{array}{l}\text { MSDS/SDS, Literature: ND } \\
\text { Predicted: Fish LC } \text { }_{50}>1000 \\
\mathrm{mg} / \mathrm{L} 96 \mathrm{~h} ; \mathrm{SW}>1000 \mathrm{mg} / \mathrm{L} \\
\text { (Ecosar v1.11); >1000 mg/L } \\
\text { (PNN); >1000 mg/L (Neutral } \\
\text { Organics QSAR) }\end{array}$ & $\begin{array}{l}\text { MSDS/SDS: Measured oxygen demand: } \\
\text { BOD }^{\circ} 23.4 \mathrm{mg} / \mathrm{L} ; \mathrm{COD}^{\mathrm{p}} 61,245 \mathrm{mg} / \mathrm{L} \\
\text { Literature: Raphidocelis }{ }^{\mathrm{q}}(\text { Pseudokirchneriella } \\
\text { or Selenastrum) } \mathrm{EC}_{50}>1000 \mathrm{mg} / \mathrm{L} 72 \mathrm{~h}[79] . \\
\text { Predicted: Green algae } \mathrm{EC}_{50}>1,000 \mathrm{mg} / \mathrm{L} \\
\text { (Ecosar v1.11) }\end{array}$ & $\begin{array}{l}\text { MSDS/SDS: } \\
\text { Biological waste } \\
\text { treatment }\end{array}$ \\
\hline $\begin{array}{l}\text { Clindamycin } \\
24729-96-2 \\
(\text { CLEOCIN } ®)\end{array}$ & $\begin{array}{l}6 \\
(3,0,3)\end{array}$ & $\begin{array}{l}\text { Cannot be } \\
\text { excluded }\end{array}$ & $\begin{array}{l}\text { MSDS/SDS: Daphnia EC } \mathrm{EC}_{50} \\
0.07 \mathrm{mg} / \mathrm{L} \text { 48h. } \\
\text { Literature: ND } \\
\text { Predicted: Daphnia } \text { LC }_{50} \\
435 \mathrm{mg} / \mathrm{L} \text { 48h; mysid LC } \\
261 \mathrm{mg} / \mathrm{L} \text { 96h (Ecosar } \\
\text { v1.11) }\end{array}$ & 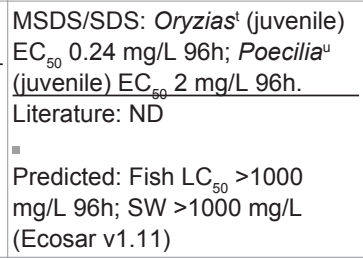 & 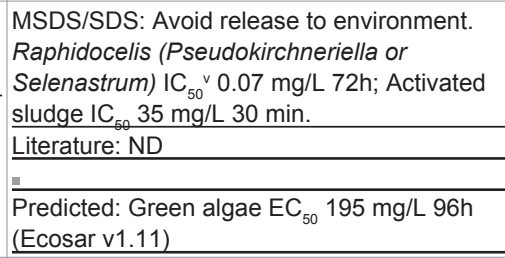 & $\begin{array}{l}\text { MSDS/SDS: } \\
\text { Chemical } \\
\text { incinerator with } \\
\text { afterburner and } \\
\text { scrubber }\end{array}$ \\
\hline $\begin{array}{l}\text { Levofloxacin } \\
100986-85-4 \\
(\text { LEVAQUIN } ®)\end{array}$ & $\begin{array}{l}8 \\
(3,3,2)\end{array}$ & Insignificant & 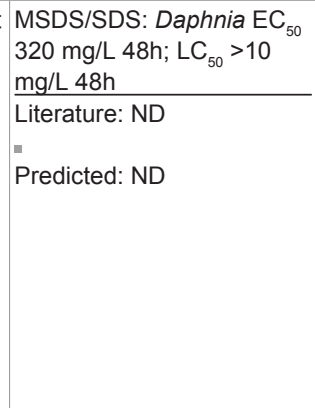 & $\begin{array}{l}\text { MSDS/SDS: Pimephaleu }{ }^{\mathrm{w}} \mathrm{LC}_{50} \\
>10 \mathrm{mg} / \mathrm{L} 7 \mathrm{~d} ; \text { Lepomis }^{\times} \mathrm{LC}_{50} \\
>950 \mathrm{mg} / \mathrm{L} \text { 96h. } \\
\text { Literature: ND } \\
\text { Predicted: ND }\end{array}$ & 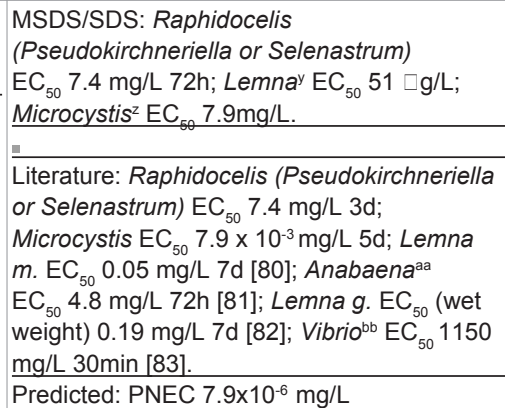 & MSDS/SDS: ND \\
\hline
\end{tabular}


A total of 12,345 drug records for dispensing and waste collection were reviewed from 2008 and 2009. There were 4,889 records for a one week period in April, 2009 at the 630 bed Albany Medical Center Hospital and 7,257 records from August, 2008 through February, 2009 for the 20 bed South Clinical Campus of Albany Medical Center. The contents of 199 pharmaceutical waste collection containers from August, 2008 through February, 2009 placed at SCC were sorted by hand and the results tabulated by location, medication form and weight of units discarded. Weights are for active ingredient, e.g., a $1 \mathrm{~g}$ dose of cefazolin was recorded as $1 \mathrm{~g}$ regardless of the total weight of the drug formulation. Predicted ecotoxicity values derived from computer programs (e.g., Aster, Ecosar, and Neutral Organics QSAR. Oasis Forecast M, PNN, Topkat, etc.).in excess of $1000 \mathrm{mg} / \mathrm{L}(100 \mathrm{mg} / \mathrm{dL}$ or $0.1 \%$ ) are recorded as $>1000 \mathrm{mg} / \mathrm{L}$

a. Antibiotic drug: includes: anti-infective, anti-viral, anti-parasitic and anti-microbial prescription pharmaceuticals used to treat human infectious disease.

b. Ecotoxicity: from material safety data sheets (MSDSs), open literature or predicted from computer programs.

c. PBT: persistence, bioaccumulation, and toxicity $(0-3$ range for each, with zero being the most benign).

d. Risk: ratio of PEC / PNEC where PEC/PNEC <0.1 = "insignificant"; PEC/PNEC is $0.1-1$ = "low"; PEC/PNEC is $1-10=$ "moderate"; and if the PEC/PNEC is $>10=$ "high". Drugs are listed as "cannot be excluded" if insufficient evidence exists to reach a numeric ratio.

e. Disposal: from MSDS, does not apply to consumers or end users.

f. ND: no data available.

g. Daphnia: crustacean, also known as (aka) "water flea" - all Daphnia referenced in Table 1 are magna, unless otherwise specified

h. $\quad \mathrm{LC}_{50}$ : lethal concentration that kills $50 \%$ of the test organisms - acute toxicity.

i. Mysid: crustacean, "mysid shrimp".

j. Predicted: modeled values for ecotoxicity as reported in Ecosar Volume 1.11 or in the OECD CCRWEB (http://webnet.oecd.org/CCRWEB/Search.aspx last accessed 3/12/14). OECD. Ecological categorization results from the Canadian domestic substance list. Paris, France: Organisation for Economic Cooperation and Development.

k. $\quad \mathrm{EC}_{50}$ : concentration of a material which is expected to cause an adverse biological effect on $50 \%$ of the test organisms (e.g. impede movement or growth) acute toxicity.

I. PNEC: Predicted No Effect Concentration, highest modeled concentration of a substance that does not have a harmful effect in the environment.

m. Salmo: Fish, "salmon" or "trout".

n. Artemia: Crustacean, "brine shrimp".

o. BOD: Biochemical Oxygen Demand is the amount of dissolved oxygen needed by aerobic biological organisms in a body of water to break down organic material present at a certain temperature over a specific time period.

p. COD: Chemical Oxygen Demand is the standard method for indirect measurement of the amount of pollution (that cannot be oxidized biologically) in a sample of water.

q. Raphidocelis aka Pseudokirchneriella or Selenastrum: green algae.

r. Oncorhynchus: fish, "salmon" or "trout".

s. $\mathrm{ErC}_{50}$ or $\mathrm{EbC}_{50}$ means $\mathrm{EC}_{50}$ in terms of reduction of growth rate.

t. Oryzias: fish, Ricefish.

u. Poecilia: fish, "guppy" or "molly".

v. $\quad I_{50}$ : inhibitory concentration $\left(\mathrm{IC}_{50}\right)$ is a measure of the effectiveness of a substance in inhibiting a specific biological or biochemical function $50 \%$ of the time acute toxicity.

w. Pimephales: fish, "fathead minnow".

x. Lepomis: fish, "sunfish".

y. Lemna: Vascular plant, "duckweed".

z. Microcystis: blue green algae.

aa. Anabaena: blue green algae.

bb. Vibrio: luminescent gram negative bacteria.

\section{Metabolism and excretion of $\mathrm{Ab}$}

As depicted in Table 2, all of the "wasted", discarded or dispensed $\mathrm{Ab}$ were excreted as parent compound in the urine and or feces of human patients at levels up to $90-100 \%$ of the administered dose. Three (ceftriaxone, clindamycin and levofloxacin) of these $\mathrm{Ab}$ underwent metabolism in vivo and active metabolites were formed from clindamycin. Only levofloxacin formed potentially reversible drug conjugates (predominantly glucuronides) which were excreted in the urine, feces or underwent enterohepatic recirculation (Table 2).

\section{Discussion}

The present communication found that only $1.3 \mathrm{~kg}$ of $\mathrm{Ab}$ was wasted (of $77 \mathrm{~kg}$ dispensed) at two hospitals in Albany, New York over a two year period. Others have reported higher levels of wasting of antibiotics and pharmaceuticals from healthcare facilities [1012,38-39]. In previous studies [33,34], wasting of propofol and other injectable drugs or controlled substances (CS) was much higher (e.g., 41 liters of propofol emulsion, other liquid injectable surgical drugs and $8.5 \mathrm{~kg}$ of CS) from the same facilities reported herein. This disparity between $\mathrm{Ab}$ wasting and other pharmaceuticals may be attributable to the longstanding process of antibiotic stewardship [40]. Although originally promulgated to combat the rising phenomena of bacterial resistance and decreasing efficacy of drug treatments for microbial diseases [41-44], these guidelines for antimicrobial stewardship could be applied to other classes of pharmaceuticals and lead to reductions in drug dispensing, drug wasting and environmental contamination [45]. This would supplement the process for lower dose prescribing advocated by Daughton and Ruhoy [1].

In the present study, we wished to determine which $\mathrm{Ab}$ contribute the greatest weight of waste. We find that both wasting and dispensing were amenable to application of the "Pareto Principle" also known as the $80-20$ rule [46]. We have previously applied this to propofol and controlled substances $[33,34]$ while others have applied this to hospital processes [47-49]. In the present study, vancomycin was the most frequently wasted or discarded $(0.4 \mathrm{~kg})$ and dispensed $(22 \mathrm{~kg})$ $\mathrm{Ab}$ at the AMCH and SCC. Six other Ab's (bacitracin, polymyxin B, cefazolin, ceftriaxone, levofloxacin, clindamycin) together represent over $85 \%$ by weight of the $\mathrm{Ab}$ wasted/discarded or dispensed at $\mathrm{AMCH}$ and SCC. Others have found the top Ab discarded by weight vary widely by the facility studied or by the country of origin $[12,38$ $39,50]$. Thus each facility must determine its own profile of Ab wasting to direct the most effective $\mathrm{Ab}$ waste reduction plan.

Vancomycin is a powerful first line $\mathrm{Ab}$ and it is associated with 
Table 2: Summary of the Metabolism and Excretion of Antibiotic / Antimicrobial Drugs Dispensed and / or Wasted at an Academic Medical Center Hospital and a Surgical Care Center in Albany, NY.

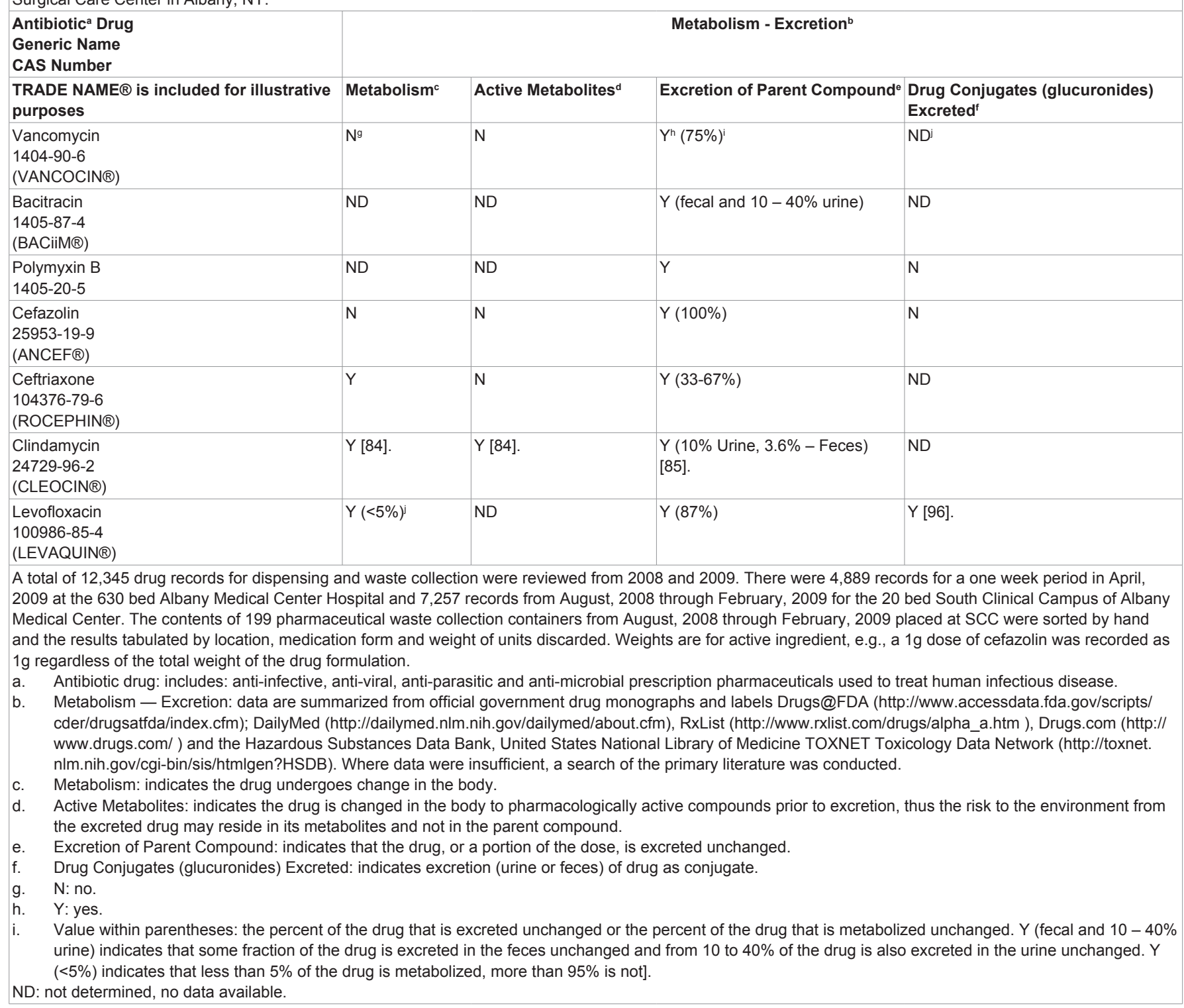

induction of vancomycin - resistant enterococci (VRE) bacteria [51,52]. As shown in this publication, a dearth of ecotoxicity data for vancomycin is available either from the manufacturer or in the open literature. Given that this $\mathrm{Ab}$ is the most wasted as well as most frequently dispensed, vancomycin should be a high priority for ecotoxicity investigations. Interestingly, $75 \%$ of a vancomycin dose is excreted without significant in vivo metabolism, production of active metabolites or formation of glucuronides, so efforts to limit vancomycin dispensing as well as wasting would be needed to reduce hospital discharges to the environment.

One goal of the present study was to test whether sources of ecotoxicologic information, readily available to healthcare environmental professionals, would be helpful in assessing the environmental impact of drug wasting/dispensing practices [53-58]. Unfortunately, we could find no "silver bullet".
Persistence [59], is an important quality of an environmental contaminants harmful potential. For Ab, long lived residues provide a continuing selection pressure for antimicrobial resistance $[60,61]$. Similarly, bioaccumulation [62,63], is a function of amplification within the environment and indirectly is seen with increasing concentrations. In the present study none of the top wasted $\mathrm{Ab}$ were rated for persistence $(\mathrm{P})$ or bioaccumulation $(\mathrm{B})$ while of the top 6 dispensed $\mathrm{Ab}, 3$ were rated as persistent and only one (levofloxacin) was bioaccumulative.

The toxicity component of the PBT index (Stockholm County Council, 2014) is based on the results of OECD Tests 201, 202 and 203 [64-66]. In the present study, we found clindamycin to be scored very highly toxic with levofloxacin and ceftriaxone of high to moderate toxicity respectively. 


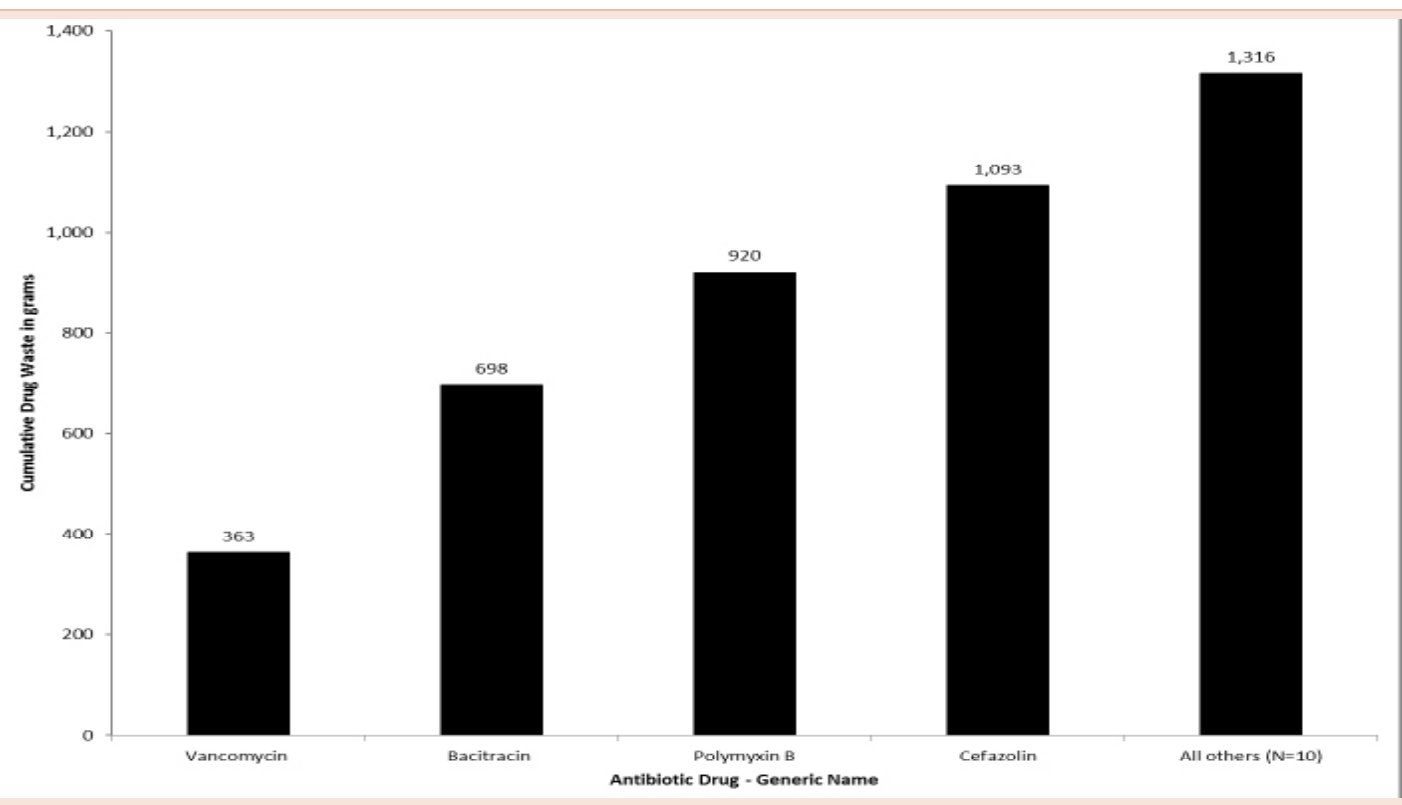

Figure 1: Bar graph of cumulative antibiotic drug waste (in grams) from two healthcare facilities over two years (2008-2009). A total of 12,345 drug records for dispensing and waste collection were reviewed from 2008 and 2009. There were 4,889 records for a one week period in April, 2009 at the 630 bed Albany Medical Center Hospital and 7,257 records from August, 2008 through February, 2009 for the 20 bed South Clinical Campus of Albany Medical Center. The contents of 199 pharmaceutical waste collection containers from August, 2008 through February, 2009 placed at SCC were sorted by hand and the results tabulated by location, medication form and weight of units discarded. Weights are for active ingredient, e.g., a $1 \mathrm{~g}$ dose of cefazolin was recorded as $1 \mathrm{~g}$ regardless of the total weight of the drug formulation. N.B., Antibiotic drug includes: anti-infective, anti-viral, anti-parasitic and anti-microbial prescription pharmaceuticals used to treat human infectious disease. In this study, four drugs accounted for over $80 \%$ of the drug waste.

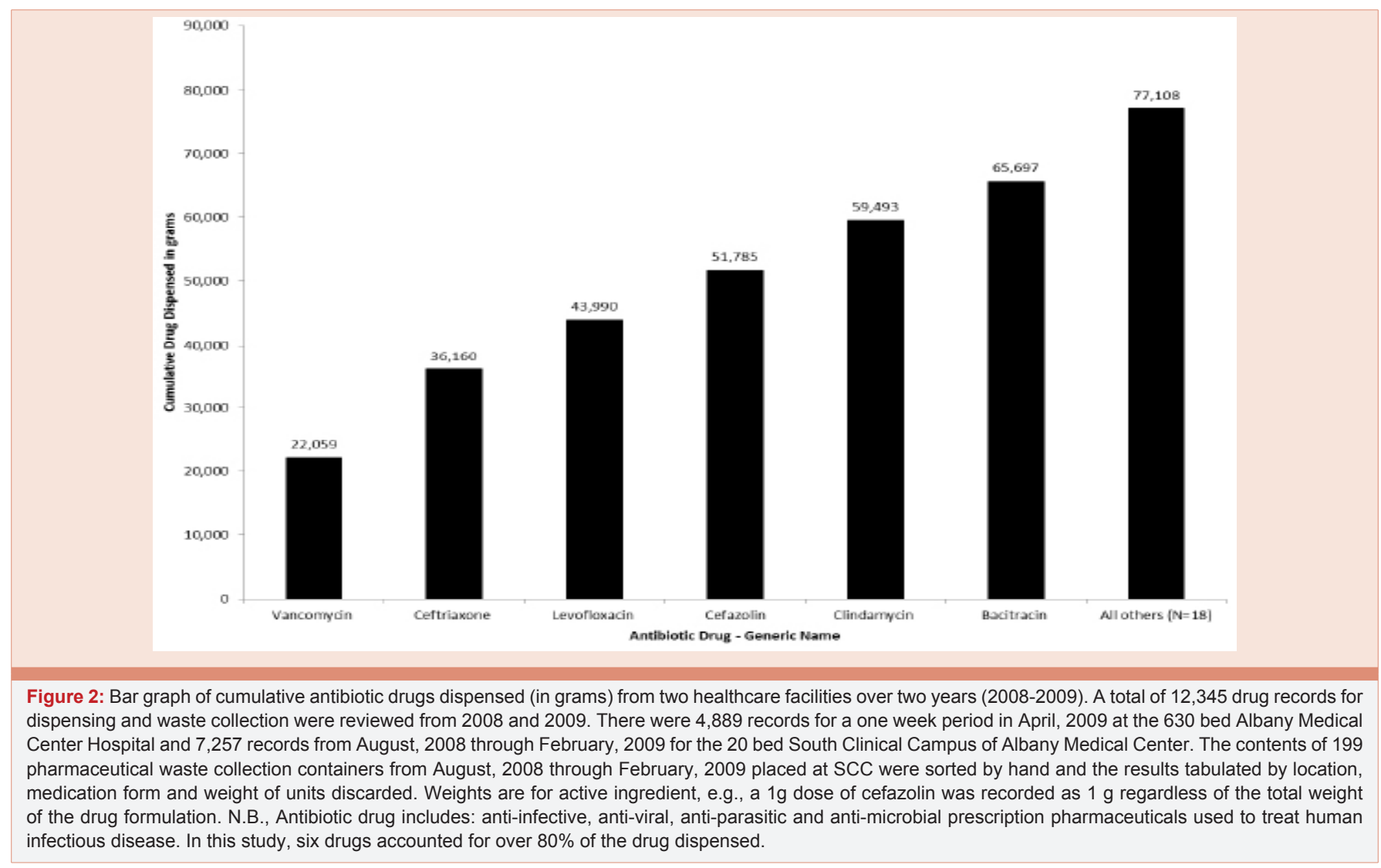

Citation: Mankes RF, Silver CD (2016) Hospital Antibiotic Wasting and Evaluation of Potential Ecologic Effects. Ann Environ Sci Toxicol 1(1): 012-022 
MSDSs are prepared by manufacturers for their products (for a more complete discussion of MSDS / SDS see the OSHA Hazard Communication Standard:

http://www.osha.gov/dsg/hazcom/msdsformat.html ). Of the top 4 wasted $\mathrm{Ab}$, only the MSDS for bacitracin reported a $48 \mathrm{~h} \mathrm{EC}_{50}$ of $30 \mathrm{mg} / \mathrm{L}$. Of the top 6 dispensed Ab only 3 (ceftriaxone, clindamycin and levofloxacin) reported ecotoxicity data for Daphnia, fish and algae in the MSDS. Of these, clindamycin was very toxic to Daphnia, fish (Oryzias and Poecilia), and Raphidocelis algae. Levofloxacin the most toxic to Lemna (Duckweed - aquatic plant). As noted in our previous communication for controlled substances [34], we would recommend more complete aquatic toxicity laboratory data (e.g., $\mathrm{EC}_{50}$ or $\mathrm{LC}_{50}$ values for Daphnia, fish, algae and bacteria) be included in manufacturer MSDSs for the most frequently wasted/dispensed $\mathrm{Ab}$ drugs, rather than an over reliance on PBT or the environmental risk ratio.

In the present study, all of the Ab were excreted in whole or in part as active drug and/or drug conjugates. Kummerer [50], opined that for the $\mathrm{Ab}$ in use in Germany, overall $70 \%$ of $\mathrm{Ab}$ were excreted unchanged. As noted by others [67,68] our data suggest that for bacitracin, cefazolin polymyxin B and vancomycin, excretion of $\mathrm{Ab}$ from patients, with or without direct hospital wasting, would be the major source of these pharmaceuticals in hospital effluent. Unfortunately, little data are available in the open literature for wastewater concentrations of these $\mathrm{Ab}[11,69,70]$. Based on the present study, we believe that the weight (grams) of $\mathrm{Ab}$ dispensed may be a more complete measure of contamination than grams of $\mathrm{Ab}$ recorded as wasted at bedside alone. This would not be true if the $\mathrm{Ab}$ studied were not excreted as active drug or as conjugates (primarily glucuronides) or if it were completely metabolized.

\section{Disposal and destruction of Ab waste}

Recommendations for disposal methods are confusing and conflicting [71-73]. Incineration is most commonly recommended for disposal of Ab by the MSDSs for the drugs examined in the current study. Of all of the Ab considered in this study, only sulfadiazine (Supplemental Table 1) meets the proposed criteria as a "hazardous waste pharmaceutical" requiring adherence to the proposed changes and additions to the Resource Conservation and Recovery Act (RCRA). These proposed rules [74], prohibit flushing and encourage incineration of pharmaceutical wastes. Seehusen and Edwards [75], surveyed disposal of medication practices and found incineration to be the best disposal option currently available. In any event, clear and detailed disposal recommendations are needed for all $\mathrm{Ab}$ and should be included in a manufacturer's MSDS/SDS. This would provide guidance and clarity to healthcare environmental professionals and pharmacy staff alike in designing and implementing pharmaceutical waste programs. In the present study, drugs were discarded directly into pharmaceutical waste containers which were then sorted and shipped via commercial waste transporter to a permitted hazardous waste incineration facility (so called TSDF) and appropriate documentation maintained throughout.

\section{Conclusions}

The present communication extends and expands our earlier observations on pharmaceuticals wasting from an acute care surgical hospital and an academic medical center in Albany, New York. We found a limited number of antibiotic / antimicrobial drugs accounted for the vast majority of $\mathrm{Ab}$ drug wasting, primarily vancomycin. For the Ab's most frequently dispensed and wasted, environmental toxicity data including estimates of persistence, bioaccumulation and toxicity to aquatic organisms such as fish, bacteria and algae were sparse, conflicting and in some cases (vancomycin) absent. These Ab's were in large measure excreted as active compounds in the urine and feces with the potential to facilitate drug resistance in organisms in the environment. Overall wasting of Ab's appeared to be much less than expected based on our prior studies of surgical drugs and controlled substances, perhaps due to adherence to the principles of antibiotic stewardship. We conclude, in agreement with others [1], that extension of these guidelines [40-42], from Ab to all other drugs used in healthcare would result in significant reductions in drug wasting. We also conclude, in agreement with proposed USEPA guidelines [74], that waste drug disposal should not involve flushing but rather controlled and regulated incineration in commercial facilities as commonly recommended by the manufacturer's MSDS.

\section{Acknowledgements}

The technical assistance of Laurie DeWeerdt, BS and Peter Gorman, BS and the assistance of Union College interns Lindsey Walaski and Kelsey Powers in review of the literature is gratefully acknowledged. Supported in part by a US EPA grant X9-97256506-0 to RF Mankes.

\section{Supplemental Data}

Supplemental Figure 1 depicts the cumulative drug waste in grams for 10 "other" Abs shown in Figure 1. Supplemental Figure 2 depicts the cumulative dispensing of the "other" $18 \mathrm{Ab}$ shown in Figure 2. Supplemental Figure 3 depicts the percent of each $\mathrm{Ab}$ wasted over a two year period. Supplemental Table 1 summarizes the ecotoxicity data available for the other $\mathrm{Ab}$ wasted, discarded or dispensed not amongst the top Ab. Supplemental Table 2 depicts the human pharmacokinetic data available for the other Ab wasted, discarded or dispensed not amongst the top Ab.

\section{References}

1. Daughton C, Ruhoy I (2013) Lower-dose prescribing: Minimizing "side effects" of pharmaceuticals on society and the environment. Sci Tot Environ 443: 324-337.

2. Daneshvar A, Aboulfadl K, Viglino L, Brozeus R, Sauve S, et al. (2012) Evaluating pharmaceuticals and caffeine as indicators of fecal contamination in drinking water sources of the greater Montreal region. Chemosphere 88: 131-139.

3. Esteban S, Valcarcel Y, Catal M, Castromil MG (2012) Psychoactive pharmaceutical residues in the watersheds of Galicia (Spain). Gac Sanit 26: 457-459.

4. Ferrari F, Gallipoli A, Balderacchi M, Ulaszewska M, Capri E, et al. (2011) Exposure of the main Italian river basin to pharmaceuticals. J Toxicol ID 989270.

5. Ferrer I, Zweigenbaum JA, Thurman EM (2010) Analysis of 70 Environmental Protection Agency priority pharmaceuticals in water by EPA Method 1694. J Chromatogr A 1217: 5674-5686.

6. Fram M, Belitz K (2011) Occurrence and concentrations of pharmaceutical 
compounds in groundwater used for public drinking-water supply in California. Sci Tot Environ 409: 3409-3417.

7. Hedgespeth $M$, Sapozhnikova $Y$, Pennington $P$, Clum A, Fairey A, et al (2012) Pharmaceuticals and personal care products (PPCPs) in treated wastewater discharges into Charleston Harbor, South Carolina. Sci Total Environ 437: 1-9.

8. Moldovan Z, Chira R, Alder AC (2009) Environmental exposure of pharmaceuticals and musk fragrances in the Somes River before and after upgrading the municipal wastewater treatment plant Cluj-Napoca, Romania. Environ Sci Pollut Res Int 1: S46-54

9. Subedi B, Du B, Chambliss CK, Koschorreck J, Rüdel H, et al. (2012) Occurrence of pharmaceuticals and personal care products in German fish tissue: A national study. Environ Sci Technol 46: 9047-9054.

10. Escher R, Baumgartner R, Koller M, Treyer K, Lienert J, et al. (2011) Environmental toxicology and risk assessment of pharmaceuticals from hospital wastewater. Water Res 45: 75-92.

11. Le Corre K, Ort C, Kateley D, Allen B, Escher B, et al. (2012) Consumptionbased approach for assessing the contribution of hospitals towards the load of pharmaceutical residues in municipal wastewater. Environ Int 45: 99-111.

12. Sim W, Lee J, Lee E, Shin S, Hwang S, et al. (2011) Occurrence and distribution of pharmaceuticals in wastewater from households, livestock farms, hospitals and pharmaceutical manufactures. Chemosphere 82: 179186

13. Phillips $P$, Smith S, Kolpin D, Zaugg S, Buxton H, et al. (2010) Pharmaceutical formulation facilities as sources of opiods and other pharmaceuticals to wastewater treatment plant effluents. Environ Sci Technol 44: 4910-4916.

14. Sanchez W, Sremski W, Piccini B, Palluel O, Maillot-Marechal E, et al (2011) Adverse effects in wild fish living downstream from pharmaceutical manufacture discharges. Environ Int 37: 1342-1348.

15. Bernot M, Smith L, Frey J (2013) Human and veterinary pharmaceutical abundances and transport in a rural central Indiana stream influenced by confined animal feeding operations (CAFOs). Sci Tot Environ 445-446: 219230

16. Cavenati S, Carvalho P, Almeida C, Basto M, Vasconcelos M (2012) Simultaneous determination of several veterinary pharmaceuticals in effluents from urban, livestock and slaughterhouse wastewater treatment plants using a simple chromatographic method. Water Sci Technol 66: 603-611.

17. Sellin M, Snow D, Schwartz M, Carte BJ, Kolok AS (2009b) Agrichemicals in Nebraska, USA, watersheds: occurrence and endocrine effects. Environ Toxicol Chem 28: 2443-2448.

18. Christian T, Schneider RJ, Farber HA, Skutlarek D, Meyer MT, et al. (2003) Determination of antibiotic residues in manure, soil and surface waters. Acta Hydrochim Hydrobiol 31: 36-44.

19. Novo A, Andre S, Viana P, Nunes O, Manaia C (2013) Antibiotic resistance, antimicrobial residues and bacterial community composition in urban wastewater. Water Res 47: 1875-1887.

20. Costanzo S, Murby J, Bates J (2005) Ecosystem response to antibiotics entering the aquatic environment. Marine Pol Bull 51: 218-223.

21. Kinney C, Furlong E, Werner S, Cahill J (2006) Presence and distribution of wastewater-derived pharmaceuticals in soil irrigated with reclaimed water. Environ Toxicol Chem 25: 317-326.

22. Kummerer K, Alexy R, Huttig J, Scholl A (2004) Standardized tests fail to assess the effects of antibiotics on environmental bacteria. Water Res 38 : 2111-2116.

23. Hernando M, Mezcna M, Fernandez-Alba A, Barcelo D (2006) Environmental risk assessment of pharmaceutical residues in wastewater effluents, surface waters and sediments. Talanta 69: 334-342.

24. Hendricks R, Pool E (2012) The effectiveness of sewage treatment processes to remove faecal pathogens and antibiotic residues. J Environ Sci HIth 47: 289-297.
25. Hirsch R, Ternes T, Haberer K, Kratz K-L (1999) Occurrence of antibiotics in the aquatic environment. Sci Total Environ 225: 109-118.

26. Batt AL, Bruce IB, Aga DS (2006) Evaluating the vulnerability of surface waters to antibiotic contamination from varying wastewater treatment plant discharges. Environ Pollution 142: 295-302.

27. Kolpin D, Furlong E, Meyer M, Thurman E, Zaugg S, et al. (2002) Pharmaceuticals, hormones, and other organic wastewater contaminants in U.S. streams 1999-2000: A national reconnaissance. Environ Sci Technol 36: $1202-1211$

28. Kolpin D, Skopec M, Meyer M, Furlong E, Zaugg S (2004) Urban contribution of pharmaceuticals and other organic wastewater contaminants to streams during differing flow conditions. Sci Total Environ 328: 119-130.

29. Lindsey M, Meyer M, Thurman E (2001) Analysis of trace levels of sulphonomide and tetracycline antimicrobials in groundwater and surface waters using solid-phase extraction and liquid chromatography/mass spectrometry. Analytical Chemistry 73: 4640-4646.

30. Sacher F, Lange F, Brauch H, Blankenhorn I (2001) Pharmaceuticals in groundwaters: analytical methods and results of a monitoring program in Baden-Wurttemberg, Germany. J Chromatog A 938:199-210.

31. Dolliver H., Kumar K, Gupta SC (2007) Sulfamethazine uptake by plants from manure-amended soil. J Environ Qual 36: 1224-1230.

32. Kong W, Zhu Y, Fu B, Marschner P, He J (2006) The veterinary antibiotic oxytetracycline and $\mathrm{Cu}$ influence functional diversity of the soil microbial community. Environ Pollut 143:129-137.

33. Mankes R (2012) Propofol wastage in anesthesia. Anesth Analg 114: 1091 1092.

34. Mankes R, Silver C (2013) Quantitative study of controlled substance bedside wasting, disposal and evaluation of potential ecologic effects. Sci Tot Environ 444: 298-310.

35. Moore D, Breton R, MacDonald D (2003) A comparison of model performance for six quantitative structure-activity relationship packages that predict acute toxicity to fish. Environ. Toxicol. Chem 22: 1799-1809.

36. Singh K, Gupta S, Rai P (2013) Predicting acute aquatic toxicity of structurally diverse chemicals in fish using artificial intelligence approaches. Ecotoxicol Environ Saf 95: 221-233.

37. Worth AP, Cronin MT, Walker JD, Jaworska JS, Comber MH, et al (2013) Use of QSARs in international decision-making frameworks to predict ecologic effects and environmental fate of chemical substances. Environ Health Perspect 111: 1376-90.

38. Oliveira T, Murphy M, Mendola N, Wong V, Carlson D, et al. (2015) Characterization of Pharmaceuticals and Personal Care products in hospital effluent and waste water influent/effluent by direct-injection LC-MS-MS. Sci Tot Environ 518-519: 459-478.

39. Santos L, Gros M, Rodriguez-Mozaz S, Delerue-Matos C, Pena A, et al. (2013) Contribution of hospital effluents to the load of pharmaceuticals in urban wastewaters: Identification of ecologically relevant pharmaceuticals. Sci Tot Environ 461-462: 302-316.

40. Marr J, Moffet H, Kunis C (1988) Guidelines for improving the use of antimicrobial agents in hospitals: A statement by the infectious disease society of America. J Inf Dis 157: 869-876.

41. Aldeyab M, Kearney M, McElnay J, MaGee F, Conlon G, et al. (2012) Antibiotic use: A point prevalence survey of antibiotic use in four acutecare teaching hospitals utilizing the European Surveillance of Antimicrobial Consumption (ESAC) audit tool. Epidemiol 140: 1714-1720.

42. Doron S, Davidson LE (2011) Antimicrobial stewardship. Mayo Clin Proc 86: 1113-1123

43. Leekha S, Terrell C, Edson RS (2011) General principles of antimicrobial therapy. Mayo Clin Proc 86: 156-167.

44. Heintz B, Halilovic J, Christensen C (2011) Impact of a multidisciplinary 
team review of potential outpatient parenteral antimicrobial therapy prior to discharge from an academic medical center. Ann Pharmacother 45: 13291337.

45. Page A (1971) Translation of Manuale di Economia Politica ("Manual of political economy"). Kelley AM ISBN 978-0-678-00881-2.

46. Fasola G, Aita M, Marini L, Follador A, Tosolini M, et al. (2008) Drug waste minimisation and cost-containment in Medical Oncology: two-year results of a feasibility study. BMC Health Serv Res 8: 70

47. Khandelwal N, Duncan I, Ahmed T, Rubinstein E, Pegus C (2011) Impact of clinical oral chemotherapy program on wastage and hospitalizations. Am J Manag Care 17: e169-173.

48. Stonemetz J, Pham J, Necochea A, McGready J, Hody R, et al. (2011) Reduction of regulated medical waste using lean sigma results in financial gains for hospital. Anesthesiol Clin 29: 145-152.

49. Kummerer K (2009) Antibiotics in the aquatic environment - A review - Par I. Chemosphere 75: 417-434.

50. Banerjee T, Anupurba S (2012) Colonization with vancomycin-intermediate Staphylococcus aureus strains containing the van A resistance gene in a tertiary-care center in North India. J Clin Microbiol 50: 1730-1732.

51. Cetinkaya Y, Falk P, Mayhall C (2000) Vancomycin-resistant Enterococci. Clin Microbiol Rev 13: 686-707.

52. (2011) Committee for Medicinal Products for Human Use (CHMP). Questions and answers on 'Guideline on the environmental risk assessment of medicinal products for human use. 2011 Mar 17 European Medicines Agency Science Medicines Health

53. Deblonde T, Hartemann P (2013) Environmental impact of medical prescriptions: assessing the risks and hazards of persistence, bioaccumulation and toxicity of pharmaceuticals. Public Health 127: 312-317.

54. Hope Bk, Stone D, Fuji T, Gensemer R, Jenkins J (2010) Meeting the challenge of identifying persistent pollutants at the state level. Integr Environ Assess Manag 6: 735-748.

55. Sailaukhanuly Y, Zhakupbekova A, Amutova F, Carlsen L (2013) On the ranking of chemicals based on their PBT characteristics: comparison of different ranking methodologies using selected POPs as an illustrative example. Chemosphere 90: 112-117.

56. Strempel S, Scheringer M, Ng C, Hungerbühler K (2012) Screening for PBT chemicals among the "existing" and "new" chemicals of the EU Environ Sc Technol 46: 5680-5687

57. Zarfl C, Hotopp I, Kehrein N, Matthies M (2012) Identification of substances with potential for long-range transport as possible substances of very high concern. Environ Sci Pollut Res Int 19: 3152-3161.

58. OECD (1992a) Test No. 301: Ready Biodegradability, OECD Guidelines for the Testing of Chemicals, Section 3, OECD Publishing, Paris.

59. Bouki C, Venieri D, Diamadopoulos E (2013) Detection and fate of antibiotic resistant bacteria in wastewater treatment plants: A review. Ecotoxicol Environ Safe 91: 1-9.

60. Varela A, Ferro G, Vredenburg J, Yanık M, Vieira L, et al. (2013) Vancomycin resistant enterococci: From the hospital effluent to the urban wastewater treatment plant. Sci Total Environ 450-451: 155-161.

61. OECD (1995) Test No. 107: Partition Coefficient (n-octanol/water): Shake Flask Method, OECD Guidelines for the Testing of Chemicals, Section 1, OECD Publishing, Paris.

62. OECD (2004a) Test No. 111: Hydrolysis as a Function of pH, OECD Guidelines for the Testing of Chemicals, Section 1, OECD Publishing, Paris.

63. OECD (1992b) Test No. 203: Fish, Acute Toxicity Test, OECD Guidelines for the Testing of Chemicals, Section 2, OECD Publishing, Paris.

64. OECD (2004b) Test No. 202: Daphnia sp. Acute Immobilisation Test, OECD Guidelines for the Testing of Chemicals, Section 2, OECD Publishing, Paris.
65. OECD (2011) Test No. 201: Freshwater Alga and Cyanobacteria, Growth Inhibition Test, OECD Guidelines for the Testing of Chemicals, Section 2, OECD Publishing, Paris.

66. Daughton CG, Ruhoy IS (2009) Environmental footprint of pharmaceuticals: Significance of factors beyond direct excretion to sewers. Environ Toxicol Chem 28: 12-15

67. Stoner S (2009) A new prescription Do Not Flush your unused drugs. Conservationist 14-16.

68. Rodriguez-Mozaz S, Chamorro S, Marti E, Huerta B, Gros M, et al. (2015) Occurrence of antibiotics and antibiotic resistance genes in hospital and urban wastewaters and their impact on the receiving river. Water Res 69 : 234-242.

69. Watkinson AJ, Murby EJ, Kolpin DW, Costanzo SD (2009) The occurrence of antibiotics in an urban watershed: from wastewater to drinking water. Sci Total Environ 407: 2711-2723.

70. Food and Drug Administration (FDA) (2011) How to Dispose of Unused Medicines. FDA Consumer Health Information 1-2.

71. Herring M, Shah S, Shah S, Gupta A (2008) Current regulations and modest proposals regarding disposal of unused opioids and other controlled substances. J Am Osteopath Assoc 108: 338-343.

72. Yeh B (2010) Legal issues relating to the disposal of dispensed controlled substances. Cong Res Serv R40548.

73. US Environmental Protection Agency (2015) Management Standards for Hazardous Waste Pharmaceuticals. 80 Fed Reg 58014-58092.

74. Seehusen D, Edwards J (2006) Patient practices and beliefs concerning disposal of medications. J Am Board Fam Med 19: 542-547.

75. Delupis G, Macri A, Civitareale C, Migliore L (1992) Antibiotics of zootechnical use: effects of acute high and low dose contamination on Daphnia magna Straus. Aquatic Toxicol 22: 53-60.

76. Midvedt T (2001) Antibiotics in the environment: Zinc bacitracin -environmental toxicity and breakdown. IN: Kummerer $\mathrm{K}$ (ed). Pharmaceuticals in the Environment. Springer Berlin 77-79.

77. Migliore L, Civitareale C, Brambilla G, Dojmi di Delupis G (1997) Toxicity of several important agricultural antibiotics to Artemia. Water Res 31: 18011806.

78. Eguchi K, Nagase H, Ozawa M, Endoh Y, Goto K, et al. (2004) Evaluation of antimicrobial agents for veterinary use in the ecotoxicity test using microalgae. Chemosphere 57: 1733-1738.

79. Robinson AA, Belden JB, Lydy MJ (2005) Toxicity of fluoroquinolone antibiotics to aquatic organisms. Environ. Toxicol. Chem 24: 423-430.

80. Gonzalez-Pleiter M, Gonzalo S, Rodea-Palomares I, Leganes F, Rosal R, et al. (2013) Toxicity of five antibiotics and their mixtures towards photosynthetic aquatic organisms: Implications for environmental risk assessment. Water Res 47: 2050-2064.

81. Brain R, Johnson D, Richards S, Hanson M, Sanderson H, et al. Microcosm evaluation of the effects of an eight pharmaceutical mixture to aquatic macrophytes Lemma gibba and Myriophyllum sibiricam. Aquatic Toxicol 70: $23-40$.

82. El Najjar NH, Deborde M, Journel R, Karpel Vel Leitner NK (2013) Aqueous chlorination of levofloxacin: Kinetic and mechanistic study, transformation product identification and toxicity. Water Res 47: 121-129.

83. McEvoy GK (2007) (ed.). American Hospital Formulary Service. AHFS Drug Information 2007. American Society of Health-System Pharmacists, Inc Bethesda.

84. Hardman J, Limbird L, Gilman A (2001) (eds). Goodman and Gilman's The Pharmacological Basis of Therapeutics. 10th ed. New York, NY: McGraw-Hill 2045.

85. Hemeryck A, Mamidi RN, Bottacini M, Macpherson D, Kao M, et al. (2006) 
Pharmacokinetics, metabolism, excretion and plasma protein binding of 14C-levofloxacin after a single oral administration in the Rhesus monkey. Xenobiotica 36: 597-613.

86. Park S, Choi K (2008) Hazard assessment of commonly used agricultural antibiotics on aquatic ecosystems. Ecotoxicol 17: 526-538.

87. Liu Y, Gao B, Yue Q, Guan Y, Wang Y, et al. (2012) Influences of two antibiotic contaminants on the production, release and toxicity of microcystins. Ecotoxicol Environ Saf 77: 79-87.

88. Lützhøft H, Halling-Sørensen B, Jørgensen S (1999) Algal toxicity of antibacterial agents applied in Danish fish farming. Arch Environ Contam Toxicol 36: 1-6.

89. Backhaus T, Grimme L (1999) The toxicity of antibiotic agents to the luminescent bacterium Vibrio fischeri. Chemosphere 38: 3291-3301.

90. Gargosova H, Vavrova M, Weissmannova H, Mravcova L, Vydrova L, et al (2011) The use of methods of environmental analysis and ecological tests in the evaluation of wastewater. IN: Einschlag FSG (ed) Waste - Water Evaluation and Management. Rijeka, Croatia. InTech.

91. Ando T, Nagase H, Eguchi K, Hirooka T, Nakamura T, et al. (2007) A nove method using cyanobacteria for ecotoxicity test of veterinary antimicrobial agents. Environ Toxicol Chem 26: 601-606.

92. Harada A, Komori K, Nakada N, Kitamura K, Suzuki Y (2008) Biological effects of PPCPs on aquatic lives and evaluation of river waters affected by different wastewater treatment levels. Water Sci Technol 58: 1541-1546.

93. Isidori M, Lavorgna M, Nardelli A, Pascarella L, Parrella A (2005) Toxic and genotoxic evaluation of six antibiotics on non-target organisms. Sci Tot Environ 346: 87-98.

94. Ji K, Kim S, Han S, Seo J, Lee S, et al. (2012) Risk assessment of chlortetracycline, oxytetracycline, sulfamethazine, sulfathiazole, and erythromycin in aquatic environment: are the current environmental concentrations safe? Ecotoxicol 21: 2031-2050.

95. Marking L, Howe G, Crowther J (2011) Toxicity of erythromycin 'oxytetracycline, and tetracycline aldministered to lake trout in water baths by injection, or by feeding. Progress Fish-Culturisl 50: 197-201.

96. Straub J, Gysel D, Kastl U, Klemmer J, Sonderegger M, et al. (2012) Environmental Risk Assessment For Ancillary Substances In Biotechnological Production Of Pharmaceuticals. Environ Toxicol Chem 31: 681-687.

97. Kim P, Park Y, Ji K, Seo J, Lee S, et al. (2012) Effect of chronic exposure to acetaminophen and lincomycin on Japanese medaka (Oryzias latipes) and freshwater cladocerans Daphnia magna and Moina macrocopa, and potential mechanisms of endocrine disruption. Chemosphere 89: 10-18.

98. Ferrari B, Mons R, Vollat B, Fraysse B, Paxeus N, et al. (2004) Environmental risk assessment of six human pharmaceuticals: are the current environmental risk assessment procedures sufficient for the protection of the aquatic environment? Environ. Toxicol. Chem 23: 1344-1354.

99. Lanzky P, Halling-Sorensen B (1997) The toxic effect of the antibiotic metronidazole on aquatic organisms. Chemosphere 35: 2553-2561.

100. Bona M, Di Leva V, De Liguoro M (2014) The sensitivity of Daphnia magna and Daphnia curvirostris to 10 veterinary antibacterials and to some of their binary mixtures. Chemosphere 115: 67-74.

101.Anskjær G, Rendal C, Kusk K (2013) Effect of pH on the toxicity and bioconcentration of sulfadiazine on Daphnia magna. Chemosphere 91 1183-1188.

102. Wollenberger L, Halling -Sorensen B, Kusk KO (2000) Acute and chronic toxicity of veterinary antibiotics to Daphnia magna. Chemosphere 40: 723 730.

103. De Orte M, Carballeira C, Viana I, Carballeira A (2013) Assessing the toxicity of chemical compounds associated with marine land-based fish farms: The use of miniscale microalgal toxicity tests. Chem. Ecol 29: 554-563.

104. Bialk-Bielinska A, Stolte S, Arning J, Uebers U, Böschen A, et al. (2011) Ecotoxicity evaluation of selected sulfonamides. Chemosphere 85: 928933.

105. EMA (European Medicines Agency) (2012) Assessment report Viread international non-proprietary name: Tenofovir disoproxil fumarate.

106. Pacifici GM, Evangelisti L, Giuliani L, Metelli RM, Giordani R (1996) Zidovudine glucuronidation in human liver: interindividual variability. Int $J$ Clin Pharmacol Ther 34: 329-334.

107. Allars H, Coleman M, Norton R (1985) $1 \mathrm{H}$ nuclear magnetic resonance study of metronidazole metabolism by perfused rat liver. Eur J Drug Metab Pharmacokinet 10: 253-260.

108. Loft S, Nielsen AJ, Borg BE, Poulsen HE (1991) Metronidazole and antipyrine metabolism in the rat: clearance determination from one saliva sample. Xenobiotica 21: 33-46.

109. Verho M, Dagrosa E, Malerczyk V (1986) Clinical pharmacology of ofloxacin a new chemotherapeutic agent belonging to the gyrase inhibitor group. Infection 14: S47-53.

110. Schoondermark-van de Ven E, Vree T, Melchers W, Camps W, Galama $J(1995)$ In vitro effects of sulfadiazine and its metabolites alone and in combination with pyrimethamine on Toxoplasma gondii. Antimicrob Agents Chemother 39: 763-765.

111. Ray A, Cihlar T, Robinson K, Tong L, Vela J, et al. (2006) Mechanism of active renal tubular efflux of tenofovir. Antimicrob Agents Chemother 50: 3297-3304.

Copyright: (c) 2016 Mankes RF, et al. This is an open-access article distributed under the terms of the Creative Commons Attribution License, which permits unrestricted use, distribution, and reproduction in any medium, provided the original author and source are credited. 